\title{
PENGUKURAN PRODUKTIVITAS PERUSAHAAN TAHU DENGAN METODE OBJECTIVE MATRIX (OMAX)
}

\author{
Agus Supriyanto ${ }^{1}$, Banun Diyah Probowati ${ }^{2}$, Burhan $^{2}$ \\ ${ }^{1}$ Alumni Program Studi Teknologi Industri Pertanian, Fakultas Pertanian \\ ${ }^{2}$ Staf pengajar Program Studi Teknologi Industri Pertanian, Fakultas Pertanian \\ Korespondensi : Fakultas Pertanian, Universitas Trunojoyo Madura, \\ Jalan Raya Telang kamal Bangkalan \\ E-mail : agus_baik65@yahoo.com
}

\begin{abstract}
Persaingan industri pada era globalisasi akan semakin ketat. Perusahaan harus berusaha melakukan efisiensi dan efektivias semua kegiatannya. Oleh karena itu perlu dicari solusi untuk mengukur produktivitas dari perusahaan. Penelitian ini bertujuan untuk mengukur produktivitas perusahaan tahu. Metode yang digunakan untuk masalah ini dengan menggunakan metode Objective Matrix (OMAX). Perhitungan produktivitas perusahaan yang mengacu pada tiga kriteria yaitu jumlah pesanan, pemakaian bahan baku dan jumlah karyawan. Hasil penelitian ini menunjukkan bahwa indeks produktivitas yang diperoleh pada awal periode mencapai 1,13 kemudian pada periode berikutnya semakin turun sampai periode ketujuh yang mencapai -0.70. Jumlah pesanan tahu dari konsumen mengalami penurunan karena pengaruh musiman. Penggunaan bahan baku mengalami pemborosan sebesar $1.124 \mathrm{~kg}$ dan pada jumlah karyawan banyak yang menganggur sebanyak 49 orang sehingga perusahaan belum dikatakan memenuhi nilai produktivitas yang sesuai standar.
\end{abstract}

\section{Kata kunci: Produktivitas, Metode OMAX, Index Produktivitas}

\section{PENDAHULUAN}

Pada era globalisasi, persaingan industri akan semakin ketat. Indonesia yang pada saat ini kondisi ekonominya sedang dalam proses pemulihan akan menghadapi persaingan dunia. Oleh karena itu setiap perusahaan harus berusaha mengefisienkan dan mengefektifkan kinerja dari perusahaannya sehingga dapat menghadapi persaingan tersebut. Penilaian performa perusahaan dapat dilakukan salah satunya dengan penilaian kinerja tenaga kerja.

Perusahaan tahu merupakan salah satu jenis usaha yang menggunakan tenaga kerja manusia. Karyawan tersebut dibagi menjadi beberapa bagian yaitu bagian penerimaan bahan baku, pengolahan, pengemasan dan pemasaran. Pengukuran produktivitas tidak pernah dilakukan secara khusus di perusahaan tahu, namun produktivitas perusahaan diukur berdasarkan berdasarkan profit yang diperoleh oleh perusahaan.

Hal tersebut mendasari suatu pengukuran produktivitas tidak hanya berdasarkan profit namun dengan suatu metode pengukuran produktivitas. Metode yang digunakan yaitu menggunakan metode Objective Matrix (OMAX). Metode OMAX merupakan metode yang mengukur nilai indeks produktivitas perusahaan dengan menggunakan lebih dari satu rasio produktivitas yang dianggap penting bagi perusahaan.

Menurut Tamtomo (2008), metode OMAX mempunyai kelebihan/ keunggulan dibandingkan metode yang lainnya yaitu: Beberapa faktor yang berpengaruh terhadap peningkatan produktivitas dapat diidentifikasi dengan baik dan dapat dikuantifikasikan, Adanya pengertian bobot yang mencerminkan pengaruh masing-masing faktor terhadap peningkatan produktivitas perusahaan yang penentuannya memerlukan persetujuan manajemen. Model ini juga menggabungkan seluruh faktor yang berpengaruh terhadap peningkatan produktivitas dan dinilai ke dalam satu indikator atau indeks.

Tujuan dari penelitian ini adalah bagaimana pengukuran produktivitas 
perusahaan tahu dengan menggunakan metode OMAX.

\section{METODE PENELITIAN}

\section{Tempat Penelitian}

Penelitian dilakukan di Perusahaan tahu di Kecamatan Kamal Kabupaten Bangkalan.

\section{Pengumpulan data}

Pengumpulan data dilakukan dengan cara observasi dan wawancara. Data yang dikumpulkan berupa data bahan baku, data pekerja dan data mesin. Jumlah bahan baku diperoleh dari observasi yang dilaksanakan pada saat penelitian. Data pekerja merupakan data jumlah pekerja dalam perusahaan dalam pembuatan produk. Data jam kerja merupakan jumlah jam kerja untuk pekerja dalam bekerja sehari-hari. Wawancara dilaksanakan untuk melengkapai data yang tidak diperoleh dari hasil observasi.

\section{Pengolahan data}

\section{Identifikasi Kriteria Produktivitas}

Tahap awal yang dilakukan dalam pengukuran produktivitas dengan menggunakan metode OMAX yaitu menentukan kriteria produktivitas. Penentuan kriteria produktivitas harus sesuai dengan unit kerja pengukuran ini dilakukan. Proses penentuan kriteria produktivitas sebaiknya lebih dari satu kriteria karena mewakili keseluruhan produktivitas yang berada pada unit kerja.

\section{Perhitungan rasio kinerja}

Setelah menetapkan kriteria-kriteria yang dibutuhkan kemudian hasil dari kriteria tersebut pengukurannya diubah ke dalam bentuk rasio. Sehingga rasio tersebut menunjukkan tingkat efisiensi dan efektivitas dalam jumlah pesanan, pemakaian bahan baku, dan jumlah karyawan serta output yang dihasilkan.

\section{Penentuan target sasaran akhir (skor 10)}

Penentuan target sasaran akhir (skor 10) adalah menentukan nilai paling tinggi dari produktivitas yang telah diukur berdasarkan perhitungan Batas Kendali
Atas/BKA. BKA merupakan batas produktivitas maksimal yang mungkin dicapai perusahaan pada setiap kriteria produktivitas.

Rumus BKA dan rumus tingkat ketelitian (degree of acuracy/DA) serta tingkat keyakinan (Confident Level/CL) sebagai berikut:

(1) $\mathrm{BKA}=\mu+\mathrm{k} . \sigma$

Dengan $\sigma=\frac{\sqrt{\Sigma(X i-\mu) 2}}{2}$

(2) $\mathrm{DA}=\frac{\sigma}{\mu} \times 100 \%$

(3) $\mathrm{CL}=100 \%-\mathrm{DA}$

Keterangan:

BKA = Batas Kendali Atas

$\mu \quad=$ Rata-rata setiap kriteria yang

diukur

$\sigma \quad=$ Standar deviasi

$k \quad=$ Konstanta

$k=1$ bila CL terletak pada

$0 \% \leq \mathrm{CL} \leq 68 \%$

$k=2$ bila CL terletak pada

$68 \% \leq \mathrm{CL} \leq 95 \%$

$k=3$ bila CL terletak pada

$95 \% \leq \mathrm{CL} \leq 99,7 \%$

\section{Penentuan skor terburuk (skor 0)}

Penentuan skor 0 merupakan nilai produktivitas terburuk yang kemungkinan terjadi pada perusahaan. Nilai terburuk (skor 0) diperoleh dari niai (Batas Kendali Bawah) BKB yang merupakan nilai terkecil atau terburuk dari produktivitas yang diperoleh perusahaan. Rumus dari BKB adalah :

$$
\mathrm{BKB}=\mu-k . \sigma
$$

Keterangan :

$$
\begin{array}{ll}
\mathrm{BKB} & =\text { Batas kendali bawah } \\
k & =\text { Konstanta } \\
\sigma & =\text { Standar deviasi }
\end{array}
$$

\section{Penentuan interval produktivitas (skor 0 hingga 3 dan 3 hingga 10)}

Skor 0 hingga 3 didapatkan dari hasil interval pada skor 0 dan 3. Hasil dari interval tersebut dijadikan interval antara skor 0 hingga 3 . Skor 3 hingga 10 didapatkan dari interval dari skor 3 dan 
10. Hasil dari interval tersebut dijadikan sebagai interval dari skor 3 hingga 10.

\section{Penentuan skor, bobot dan nilai}

Skor merupakan level yang menunjukkan pengukuran kinerja produktivitas. Nilai ini diperoleh dengan cara yaitu : bila nilai kinerja lebih rendah dari nilai kinerja pada skor tertentu, namun masih lebih tinggi dari skor sebelumnya, maka nilai kinerja digolongkan pada skor sebelumnya. Bobot merupakan besarnya bobot kepentingan setiap ktriteria produktivitas terhadap total produktivitas. Besarnya nilai bobot setiap kriteria dilakukan dengan mengolah data yang diperoleh dari wawancara dan penyebaran kuisoner menggunakan model Analitycal Hierarchy Proses (AHP). Nilai diperoleh dari hasil perkalian antara skor dengan nilai bobot pada setiap kriteria yang diukur.

\section{Perhitungan nilai Performance Indicator}

Perhitungan Performance Indicator

terdiri dari tiga perhitungan, yaitu : (1) Current merupakan hasil pengukuraan produktivitas periode sekarang yang diperoleh dengan menjumlahkan nilai setiap kriteria yang diukur (2) Previous merupakan hasil pengukuran produktivitas periode sebelumnya dan (3) Index Productivity (IP) merupakan indikasi perubahan produktivitas yang terjadi pada perusahaan. Nilai index diperoleh dengan menggunakan rumus :

$\mathrm{IP}=\frac{\text { Current-previous }}{\text { previous }} \times 100 \%$

\section{Analisis data}

Analisis data yang akan dilakukan berdasarkan hasil pengukuran produktivitas tenaga kerja juga jumlah pesanan, jumlah pemakaian bahan baku dan jumlah karyawan yang bekerja serta output yang dihasilkan dan serta

\section{Evaluasi produktivitas}

Evaluasi produktivitas dilakukan dengan cara membandingkan skor yang dicapai setiap kriteria pengukuran dengan mempertimbangkan bobot setiap kriteria untuk mempengaruhi produktivitas perusahaan pada periode yang selanjutnya.

\section{HASIL DAN PEMBAHASAN}

\section{Gambaran umum perusahaan}

Data yang diperoleh dari pengamatan yang telah dilaksanakan antara lain pada jumlah pesanan, pemakaian bahan baku dan jumlah karyawan yang bekerja dapat dilihat pada tabel 1 .

Jumlah pesanan merupakan jumlah tahu yang dipesan oleh para konsumen tahu pada produsen tahu dalam setiap harinya. Sistem pemesanan tahu dapat dilakukan dengan kara menggunakan via telpon ataupun datang langsung pada perusahaan tahu.

Pemakaian bahan baku diperoleh dari bagian penerimaan bahan baku. Bahan baku yang digunakan dalam pembuatan tahu adalah biji kedelai yang didapatkan dari petani yang berasal dari Karang Penang dan Surabaya yang memiliki kualitas yang baik sehingga dapat menghasilkan tahu yang berkualitas. Bahan baku kedelai dikirim oleh pemasok dalam 1 minggu berkisar sebanyak 18 ton pada setiap pengiriman biji kedelai ke perusahaan.

Data jumlah karyawan dapat diperoleh dari direktur perusahaan yang menkatat setiap kali karyawan masuk bekerja. Setiap harinya pekerja yang bekerja tidaklah sama sehingga mempengaruhi produktivitas dari perusahaan tersebut. Dalam setiap harinya karyawan yang bekerja sebanyak 35 pekerja yang dibagi menjadi 7 bagian yaitu bagian pembuatan tahu, pengirisan tahu, bagian penggilingan kedelai, bagian tukang memasak kedelai, bagian ketel, bagian pengiriman dan bagian pencuci biji kedelai.

\section{Perhitungan Setiap Rasio Performance} Rasio performance ini menunjukkan hasil yang aktual dari pabrik pada setiap periode pengukuran. Hasil perhitungan rasio performance dapat dilihat pada tabel 2. Hasil dari perhitungan rasio performance menunjukkan bahwa nilai penkapaian tertinggi dikapai pada periode minggu ke 4 yang menunjukkan banyaknya pesanan yang diperoleh oleh perusahaan sehingga pada periode ke 4 merupakan periode yang maksimal yang diperoleh perusahaan. 
Tabel 1. Data Jumlah Pesanan, Pemakaian Bahan Baku, dan Jumlah Karyawan

\begin{tabular}{lllll}
\hline Periode & $\begin{array}{l}\text { Jumlah } \\
\text { pesanan }\end{array}$ & $\begin{array}{l}\text { Pemakaian bahan } \\
\text { baku }(\mathrm{kg})\end{array}$ & $\begin{array}{l}\text { Jumlah karyawan } \\
\text { (orang) }\end{array}$ & $\begin{array}{l}\text { Output } \\
\text { (buah) }\end{array}$ \\
\hline Minggu 1 & 1284 & 19260 & 233 & 449400 \\
Minggu 2 & 1303 & 19545 & 236 & 469080 \\
Minggu 3 & 1360 & 20400 & 243 & 505920 \\
Minggu 4 & 1386 & 20790 & 237 & 526680 \\
Minggu 5 & 1333 & 19995 & 231 & 486545 \\
Minggu 6 & 1348 & 20220 & 241 & 497412 \\
Minggu 7 & 1321 & 19815 & 241 & 464992 \\
\hline
\end{tabular}

Sumber: Perusahaan tahu di Kecamatan Kamal (2014)

Tabel 2. Rasio Performance

\begin{tabular}{|c|c|c|c|c|c|c|c|}
\hline Rasio/ periode & $\begin{array}{c}\text { Minggu } \\
1\end{array}$ & $\begin{array}{l}\text { Minggu } \\
2\end{array}$ & $\begin{array}{c}\text { Minggu } \\
3\end{array}$ & $\begin{array}{c}\text { Minggu } \\
4\end{array}$ & $\begin{array}{l}\text { Minggu } \\
5\end{array}$ & $\begin{array}{l}\text { Minggu } \\
6\end{array}$ & $\begin{array}{c}\text { Minggu } \\
7\end{array}$ \\
\hline $\begin{array}{l}\text { Output terhadap jumlah } \\
\text { pesanan }\end{array}$ & 350 & 360 & 372 & 380 & 365 & 269 & 352 \\
\hline $\begin{array}{l}\text { Output terhadap } \\
\text { pemakaian bahan baku }\end{array}$ & 23,33 & 24 & 24,8 & 25,33 & 24,33 & 24,6 & 23,46 \\
\hline $\begin{array}{l}\text { Output terhadap jumlah } \\
\text { karyawan }\end{array}$ & 1928,75 & 1987,62 & 2081,97 & 2222,27 & 3714,08 & 2063,95 & 1929,42 \\
\hline
\end{tabular}

Tabel 3. Tingkat Ketelitian, Tingkat keyakinan dan Batas kendali atas

\begin{tabular}{lrrr}
\hline \multicolumn{1}{c}{ Kriteria } & $\begin{array}{c}\text { Tingkat Ketelitian } \\
\text { ( DA) }\end{array}$ & $\begin{array}{r}\text { Tingkat Keyakinan } \\
\text { (CL) }\end{array}$ & Batas Kendali Atas (BKA) \\
\hline Jumlah pesanan & $2,771 \%$ & $97,028 \%$ & 396,541 \\
Pemakaian Bahan baku & $2,976 \%$ & $97,024 \%$ & 26,426 \\
Jumlah karyawan & $28,238 \%$ & $71,762 \%$ & 3560,554
\end{tabular}

Pada periode ke 5 mengalami penurunan sedikit yang tidak banyak berarti sedangkan penurunan yang sangat banyak pada periode ke 6 yang mengalami penurunan yang sangat dratis pada perusahaan tahu. Pada periode ke 7 kembali mengalami peningkatan kembali seperti pesanan-pesanan biasanya.

\section{Penentuan Target Sasaran Akhir (Skor 10) Pada Setiap Kriteria}

Tingkat ketelitian dan Tingkat keyakinan dihitung utnuk menunjukkan akurasi data dan juga untuk menghitung batas kendali. Setelah menentukan tingkat ketelitian dan tingkat keyakinan kemudian menentukan batas kendali atas untuk membuat batas agar tidak melebihi batas perhitungan yang sudah ditentukan dari perhitungan batas kendali atas. Perhitungan dari tingkat ketelitian, tingkat keyakinan dan batas kendali atas dapat dilihat pada tabel 3 .

Skor 10 merupakan nilai produktivitas paling maksimal yang harus dikapai perusahaan. Nilai BKA untuk kriteria jumlah pesanan sebesar 396,451 bahwa nilai produktivitas yang ingin dikapai untuk kriteria jumlah pesanan adalah 396,451. Sedangkan pada bahan baku yang diharapkan sebesar 24,426 dan pada jumlah karyawan diharapkan sebesar 2560,544.

\section{Penentuan Target Sasaran Nilai}

\section{Terburuk (Skor 0) Pada Setiap Kriteria}

Nilai dari batas kendali bawah (BKB) diperoleh sama seperti memperoleh nilai dari batas kendali atas (BKA) yaitu menghitung nilai ketelitian, nilai keyakinan kemudian menghitung nilai BKB setiap kriteria. Nilai tingkat ketelitian dan tingkat kayakinan sama dengan mencari skor 10 yang berbeda hanya pada perhitungan BKA dan BKB. Cara mencari BKA dengan menjumlah semuanya hasilnya sedangkan pada BKB mengurangi hasil dari perkalian antara konstanta dengan standart deviasi yang kemudian dikurangi dengan rata-rata setiap rasio. Hal ini dapat dilihat pada tabel 4. 
Tabel 4. Tingkat Ketelitian, Tingkat keyakinan dan Batas kendali bawah

\begin{tabular}{lrrr}
\hline \multicolumn{1}{c}{ Kriteria } & $\begin{array}{c}\text { Tingkat Ketelitian } \\
\text { (DA) }\end{array}$ & $\begin{array}{c}\text { Tingkat } \\
\text { Keyakinan } \\
\text { (CL) }\end{array}$ & $\begin{array}{r}\text { Batas Kendali } \\
\text { Bawah (BKB) }\end{array}$ \\
\hline Jumlah pesanan & $2,971 \%$ & $97,028 \%$ & 331,549 \\
Pemakaian Bahan baku & $2,976 \%$ & $97,024 \%$ & 22,094 \\
Jumlah karyawan & $28,238 \%$ & $71,762 \%$ & 990,34
\end{tabular}

Tabel 5. Penentuan interval antara skor 0-3 dan 3-10

\begin{tabular}{cccc}
\multicolumn{1}{c}{ Penentuan Interval } & Jumlah Pesanan & Pemakaian Bahan Baku & Jumlah Karyawan \\
\hline Interval 0-3 & 10,817 & 0,722 & 428,33 \\
Interval 3-10 & 4,635 & 0,309 & 183,58 \\
\hline
\end{tabular}

Tabel 6. Nilai pembobotan pada setiap kriteria pada produktivitas

\begin{tabular}{cccccc}
\hline Kriteria & I & II & III & Rata-rata & Bobot \\
\hline I & 1,00 & 5 & 3 & 3 & 0,06 \\
II & 0,2 & 1,00 & 5 & 2,06 & 0,02 \\
III & 0,33 & 0,2 & 1,00 & 0,51 & 0,05 \\
$\sum$ & 1,53 & 6,2 & 8 & 5,56 & 0,11 \\
\hline
\end{tabular}

Skor 0 merupakan nilai produktivitas paling buruk yang dijahui oleh perusahaan. Nilai BKB untuk kriteria jumlah pesanan sebesar 331,549 bahwa nilai produktivitas yang harus dibuang atau dijauhi pada kriteria jumlah pesanan adalah 331,549. Sedangkan pada bahan baku yang diharapkan sebesar 22,094 dan pada jumlah karyawan diharapkan sebesar 990,34.

\section{Penentuan Interval Antara Skor 0 Sampai 3 dan Antara Skor 3 sampai Skor 10 Pada Setiap Kriteria \\ Perhitungan interval skor diperlukan} karena untuk menentukan nilai pada setiap periode dan memberikan jarak yang sesuai dengan interval yang telah ditetapkan pada setiap kriteria yang diperoleh dari perhitungan. Perhitungan interval dapat dilihat pada tabel 5 .

\section{Perhitungan Skor, Nilai dan Bobot dengan menggunakan metode AHP}

Berdasarkan tabel 6 terlihat bahwa kriteria yang mempunyai tingkat kepentingan tertinggi ditunjukkan pada kriteria jumlah pesanan dibandingkan dengan kriteria yang lain dengan bobot 0,06. Menurut para responden jumlah pesanan sangatlah berpengaruh karena untuk menentukan jumlah tahu yang akan dibuat pada saat pembuatan tahu. Kriteria yang menunjukkan tingkat kepentingan yang kedua adalah kriteria jumlah karyawan yaitu bobotnya sebesar 0,05 yang berpengaruh pada produktivitas. Pada kriteria yang ketiga adalah kriteria pada pemakaian bahan baku yang mendapatkan bobot sebesar 0,02 pada pengukuran produktivitas. Kriteria yang mempunyai tingkat kepentingan terendah pada produktivitas menurut responden pada bahan baku dengan bobot 0,02 karena pada saat pesanan sama pekerjanya tidak ada maka bahan baku akan tidak akan diolah karena pembuatan tahu dilakukan dengan cara yang masih manual dengan menggunakan tenaga manusia.

\section{Evaluasi Masing-masing Kriteria Produktivitas}

Masing-masing kriteria mempunyai pengaruh yang besar dalam produktivitas. Evaluasi didapatkan dari setiap kriteria adalah untuk mengetahui perubahan setiap kriteria dalam mempengaruhi produktivitas yang maksimal oleh perusahaan tersebut. Hasil dari pengukuran produktivitas yang di evaluasi pada setiap kriteria adalah sebagai berikut:

\section{Produktivitas Jumlah Pesanan}

Perubahan produktivitas dalam jumlah pesanan mempunyai pengaruh terhadap perubahan produktivitas yang dicapai oleh perusahaan tahu. Perubahan tersebut dapat dievaluasi melalui skor yang menunjukkan performance produktivitas yang dicapai pada kriteria jumlah pesanan yang ditunjukkan pada tabel 7. 
Tabel 7. Pencapaian Skor Jumlah Pesanan

\begin{tabular}{lcc}
\hline Periode & Performance & Skor \\
\hline Minggu 1 & 350 & 1 \\
Minggu 2 & 360 & 2 \\
Minggu 3 & 372 & 4 \\
Minggu 4 & 380 & 6 \\
Minggu 5 & 365 & 3 \\
Minggu 6 & 369 & 4 \\
Minggu 7 & 352 & 1 \\
\hline
\end{tabular}

Pencapaian skor pada jumlah pemesan ditunjukkan pada periode keempat dengan skor 6 yang menunjukkan bahwa jumlah pesanan yang paling tinggi yang disebabkan oleh kebutuhan masyarakat terhadap produk tahu semakin banyak. Pada periode ke 5 mengalami penurunan sehingga hanya memperoleh skor 4 kemudian pada periode keenam mengalami kenaikan hanya sedikit dan pada periode ketujuh kembali mengalami penurunan yang sangat drastis melebihi dari penurunan pada periode keenam sehingga hanya mendapatkan skor 1 .

\section{Pemakaian Bahan Baku}

Perubahan produktivitas dalam pemakaian bahan baku mempunyai pengaruh terhadap perubahan produktivitas yang dicapai oleh perusahaan tahu. Perubahan tersebut dapat dievaluasi melalui skor yang menunjukkan performance produktivitas yang dicapai pada kriteria pemakaian bahan baku yang ditunjukkan pada tabel 8 .

Tabel 8 menunjukkan pemakaian bahan baku terlihat bahwa pencapaian skor terburuk pada awal-awal periode 1 dengan skor 1. Periode berikutnya mengalami peningkatan yang bagus. Pencapaian pada periode keempat adalah pencapaian skor 6 yang paling tinggi, namun juga mengalami penurunan sehingga mendapatkan skor 3 kemudian mengalami peningkatan kembali. Periode terakhir menunjukkan penurunan yang sangat drastis dan mendapatkan skor 1 pada periode ketujuh. Turunnya produktivitas pada bahan baku dipengaruhi oleh jumlah pesanan yang samakin sedikit sehingga pemakaian bahan baku mengalami penurunan sehingga banyak biji kedelai yang tidak dapat dikarnakan mengalami kerusakan.

\section{Jumlah karyawan}

Perubahan produktivitas dalam jumlah karyawan berpengaruh terhadap proses
Tabel 8. Pencapaian Skor Pemakaian Bahan Baku

\begin{tabular}{lcc}
\hline Periode & Performance & Skor \\
\hline Minggu 1 & 23,33 & 1 \\
Minggu 2 & 24,00 & 2 \\
Minggu 3 & 24,80 & 4 \\
Minggu 4 & 25,33 & 6 \\
Minggu 5 & 25,33 & 3 \\
Minggu 6 & 24,60 & 4 \\
Minggu 7 & 23,46 & 1 \\
\hline
\end{tabular}

produksi meskipun bahan baku banyak , namun masih ditentukan oleh banyaknya karyawan yang bekerja. Perubahan produktivitas yang dicapai oleh perusahaan tahu ini dapat dievaluasi melalui skor yang menunjukkan performance produktivitas yang dicapai pada kriteria pemakaian bahan baku yang ditunjukkan pada tabel 9 .

Tabel 9 menunjukkan bahwa pencapaian jumlah pekerja mempunyai nilai yang paling besar pada periode keempat dengan skor 3 . Periode berikutnya tetap stabil sehingga tidak terdapat perubahan yang berarti walaupun produktivitas menurun atau naik pada pencapaian jumlah karyawan.

\section{Evaluasi Produktivitas Total}

Evaluasi ini dilakukan untuk mengetahui sejauh mana tingkat produktivitas total yang dicapai oleh perusahaan tahu di Kecamatan kamal. Hasil pengukuran produktivitas total yang telah dicapai dapat ditunjukkan pada tabel 10.

Evaluasi indeks pencapaian yang telah dicapai oleh perusahaan tahu ini maka produktivitas total yang dicapai dapat dilihat pada gambar 1. Gambar 1 tersebut menunjukkan bahwa indek produktivitas total yang dicapai oleh perusahaan. Indeks produktivitas mengalami perubahan setiap periode, dari periode $1(1,13)$ hingga periode tujuh $(-0,70)$. Penurunan ini disebabkan banyaknya bahan baku yang terbuang sia-sia dan banyaknya karyawan yang bekerja tidak maksimal.

\section{Usulan-usulan Perbaikan Produktivitas}

Usulan perbaikan produktivitas diusulkan setelah perusahaan mengetahui hasil yang sudah dicapai dalam periode 7 minggu yang telah dilakukan pengamatan. 
Tabel 9. Pencapaian Skor Jumlah Karyawan

\begin{tabular}{lcc}
\hline Periode & Performance & Skor \\
\hline Minggu 1 & 1928,75 & 2 \\
Minggu 2 & 1987,62 & 2 \\
Minggu 3 & 2081,97 & 2 \\
Minggu 4 & 2222,27 & 3 \\
Minggu 5 & 2206,25 & 2 \\
Minggu 6 & 2063,95 & 2 \\
Minggu 7 & 1929,42 & 2 \\
\hline
\end{tabular}

Tabel 10. Perhitungan Performance Indikator

\begin{tabular}{cccc}
\hline Periode & $\begin{array}{c}\text { Produktivitas Total } \\
\text { Current }\end{array}$ & Previous & Indeks \\
\hline Minggu 1 & 0,18 & - & 0,18 \\
Minggu 2 & 0,26 & 0,18 & 44,44 \\
Minggu 3 & 0,42 & 0,26 & 61,53 \\
Minggu 4 & 0,63 & 0,42 & 50 \\
Minggu 5 & 0,34 & 0,63 & $-46,03$ \\
Minggu 6 & 0,42 & 0,34 & 23,55 \\
Minggu 7 & 0,18 & 0,42 & $-57,14$ \\
\hline
\end{tabular}

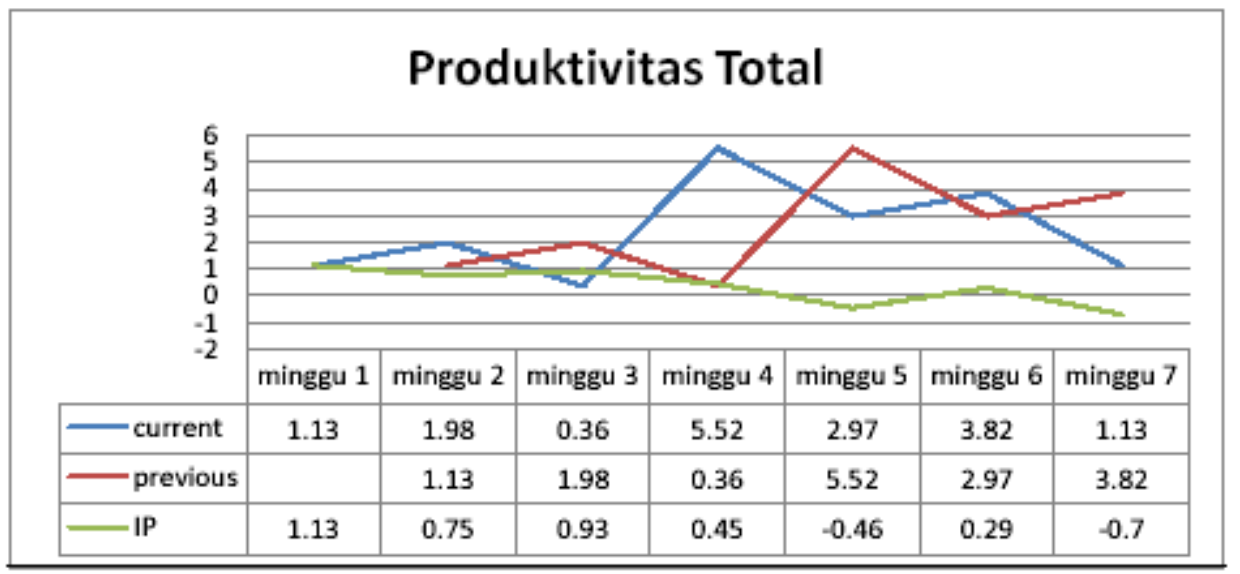

Gambar 1. Indek Produktivitas Total

Perbaikan produktivitas mengacu pada kriteria-kriteria yang telah di tetapkan antara lain jumlah pesanan, pemakaian bahan baku, dan jumlah karyawan yang bekerja. Usulan ini mengacu untuk perbaikan yang akan dating yaitu pada periode kedelapan untuk mendapatkan hasil yang maksimal yang ingin dicapai oleh perusahaan.

Berdasarkan periode minggu ketujuh atau periode terakhir pada penelitian maka dilakukan usulan perbaikan pada setiap kriteria untuk memperbaiki periode kedelapan. Data yang didapatkan pada minggu ketujuh sebagai acuan untuk mempermudah dalam perbaikan produktivitas pada perusahaan antara lain adalah :

Jumlah pesanan : 1.321 pesanan

Jumlah bahan baku $\quad: 19.815 \mathrm{~kg}$

Jumlah karyawan : 241 orang

Jumlah output $\quad: 464.992$ buah

Berdasarkan data di atas maka dapat dilakukan perbaikan produktivitas pada minggu kedelapan untuk mendapatkan hasil yang ingin dicapai oleh perusahaan. Perbaikan dalam jumlah pesanan yang tidak menentu sehingga sangat berpengaruh pada produtivitas yang dihasilkan oleh perusahaan. 
Perbaikan jumlah pesanan dilakukan agar jumlah pesanan yang tidak menentu setiap periodenya disederhanakan sehingga dilakukan perhitungan agar produktivitas dari jumlah pesanan mencapai skor 5 .

Jumlah Pesanan $=\frac{\text { Jumlah Output }(\mathrm{kg})}{\text { Nilai skor } 5}$
Jumlah Pesanan $=\frac{464992)}{373,27}$

Jumlah pesanan $=1.245,71=1.246$ pesanan

Berdasarkan dari hasil perhitungan tersebut menunjukkan bahwa output sebanyak 464.992 menghasilkan jumlah pesanan sebanyak 1.246 pesanan yang berarti pada jumlah pesanan tidak dibutuhkan perbaikan karena hasil yang sudah didapatkan melebihi dari hasil perhitungan yaitu mencapai 75 pesanan. Pada jumlah pesanan mengalami peningkatan sedikit dari perhitungan yang telah dilaksanakan.

Perbaikan pada bahan baku ini untuk mengefesiensi bahan baku yang digunakan dalam pembuatan tahu. Perbaikan produktivitas pada bahan baku untuk mencapai skor yang ingin dicapai oleh perusahaan yaitu skor 5 .

Jumlah Bahan baku $=\frac{\text { Jumlah Output }(\mathrm{kg})}{\text { Nilai skor } 5}$

Jumlah bahan baku $=\frac{464992)}{24,878}$

Jumlah bahan baku $=18.690,8=18.691 \mathrm{~kg}$

Pada perbaikan produktivitas bahan baku untuk menghasilkan output sebanyak 464.992 buah hanya dibutuhkah bahan baku sebanyak $18.691 \mathrm{~kg}$. Sebelum dilakukan perbaikan bahan baku yang diperlukan untuk mendapatkan output sebanyak 464.992 buah memerlukan bahan baku sebanyak 19.815 sehingga banyak bahan baku yang terbuang sia-sia pada saat pengolahan pembuatan tahu. Bahan baku yang terbuang atau tidak dipakai yaitu sebanyak $1.124 \mathrm{~kg}$. Seharusnya bahan baku sebanyak 19.815 dapat menghasilakan output yang melebihi dari 464.992 hasil perhitungan pertama kali tersebut.

Perbaikan pada jumlah karyawan dalam meningkatkan indek produktivitas perusahaan untuk mencapai hasil yang maksimal dari pengolahan tahu. Perbaikan pada jumlah karyawan untuk mendapatkan skor 5 yang ingin dicapai oleh perusahaan adalah :

Jumlah karyawan $=\frac{\text { Jumlah Output }}{\text { Nilai skor } 5}$

Jumlah karyawan $=\frac{464992)}{2642,49}$

Jumlah karyawan $=175,96$ orang $/$ minggu $=176$ orang $/$ minggu

Pada perbaikan produktivitas jumlah karyawan untuk menghasilkan output sebanyak 464.992 buah hanya dibutuhkah jumlah karyawan sebanyak 176 orang/minggu. Sebelum dilakukan perbaikan jumlah karyawan yang diperlukan karyawan sebanyak 241 orang/minggu untuk mendapatkan output sebanyak 464.992 sehingga banyak karyawan yang menganggur atau tidak bekerja dengan sungguh-sungguh sehingga produktivitas sangatlah jauh dengan yang diharapkan oleh perusahaan. Seharusnya jumlah karyawan sebanyak 241 orang/minggu dapat menghasilkan output yang lebih banyak 464.992 buah.

Rencana usulan untuk peningkatan produktivitas di perusahaan tahu adalah mengusulkan pada jumlah pesanan, pemakaian bahan baku, dan jumlah karyawan untuk menghasilkan yang ingin dicapai oleh perusahaan dengan menggunakan perhitungan pada skor 5 untuk menghasilkan jumlah pesanan sebanyak 1.246 pesanan yang memerlukan bahan baku sebanyak $18.691 \mathrm{~kg}$ dan menggunakan karyawan sebanyak 176 orang/minggu.

\section{KESIMPULAN}

Kesimpulan dari penelitian ini adalah kinerja dari perusahaan tahu ini kurang maksimal. Hal ini oleh terjadinya penurunan indeks produktivitas dari 1,13 (periode 1) menjadi sekitar 0,70 pada periode 7 . Efek penurunan angka indeks ini ditunjukkan oleh beberapa hal ;

1. Jumlah pesanan turun yang disebabkan permintaan konsumen yang berbeda setiap hari

2. Pemborosan pemakaian bahan baku (1.124 kg kedelai yang tidak digunakan dalam produksi) 
3. Pemborosan penggunaan tenaga kerja sebanyak 49 karyawan.

\section{DAFTAR PUSTAKA}

Aplilian T. 2010. Analisis Produktivitas Tenaga Kerja Pada Pekerjaan Struktur Rangka Atap Baja. Skripsi. Surakarta : Universitas Sebelas Maret.

Avianda D, Yoanita Y, Yuniar. 2014. Strategi Peningkatan Produktivitas di Lantai Produksi Menggunakan Metode Objective Matrix (OMAX). Bandung: Reka Integra ISSN: 2338-5081. Jurusan Teknik Industri Itenas | No.01 | Vol.02 Jurnal Online Institut Teknologi Nasional Juni 2014

BPP. 2000. Tahu. Jakarta: Kantor Deputi Menegristek Bidang Pendayagunaan dan Pemasyarakatan Ilmu Pengetahuan dan Teknologi.

Faridz R, Burhan, Wijayanti AE. 2011. Pengukuran dan Analisis Produktivitas Produksi dengan Metode Objective Matrix (OMAX) di PD. Krebet Baru Malang. Universitas Trunojoyo Madura. AGROINTEK volume 5, no 2 Agustus 2011.

Gaspersz V. 2000. Manajemen Produktivitas Total: Strategi Peningkatan Produktivitas Global. Jakarta: PT. Gramedia Pustaka Utama

Katarina. 2013. Evaluasi Dan Analisis Produktivitas Dengan Menggunakan Metode Marvin E. Mundel Di PT. XYZ. e-Jurnal Teknik Industri FT USU Vol 2, No. 1, Mei 2013 pp. 48-53.

Nurdin R, Yasrin Z. 2004. Pengukuran dan Analisis Produktivitas Lini Produksi PT. XYZ dengan Menggunakan Metode Objective Matrix. Yogyakarta:

Sinulingga, S. 2010. Analisis dan Rekayasa Produktivitas. Medan : Universitas Sumatera Utara.

Sutiyono. 2006. Analisis Produktivitas Berdasarkan Pendekatan Metode American Productivity Center (APC) di PT GFI Sidoarjo. Sidoarjo: Fakultas Teknologi Industri UPN "Veteran" Jawa Timur.

Dwi Tanto. 2012. Faktor-Faktor yang Mempengaruhi Produktivitas Pekerja Pada Pengerjaan Atap Baja Ringan Di Perumahan Green Hills Malang.
Malang: Jurnal Rekayasa Sipil / Volume 6, No. 1 - 2012 ISSN 1978 5658. 